\title{
ANALISIS STRUKTUR PEREKONOMIAN DAN FAKTOR-FAKTOR YANG MEMENGARUHI PERTUMBUHAN EKONOMI SUMATERA SELATAN
}

\author{
Indrayansyah Nur ${ }^{1}$, Sri Mulatsih ${ }^{2}$, dan Alla Asmara ${ }^{2}$ \\ ${ }^{1}$ Staf Kementerian Keuangan RI \\ ${ }^{2}$ Staf Pengajar FEM IPB
}

Artikel diterima Februari 2013

Artikel disetujui untuk dipublikasikan Juli 2013

\begin{abstract}
This study aims at analyzing the structure of the economic growth in the province of South Sumatera and the factors that influence the economic growth in the region. The method to analyze the economic structure is a regional economy approach using Location Quetiont (LQ) method and Shift Share (SS) Analysis. The National Share (NS) component indicates that the higher values are the sectors on mining and minerals, agriculture and manufacturing industry. Thus, those three sectors are strongly influenced by the change in national policy. The Industry Mix (IM) component indicates that the higher values are on the sectors on transportation and communication, construction and trade, and hotel and restaurant. That indicates that those three sectors have higher growth than other sectors. The Regional Share (RS) component indicates that agriculture is the dominant sector and therefore the most competitive sector compared to industries in the national level. It is also revealed that the progressive sectors during 2001-2005 are trading, hotel, restaurant, and construction and during 2005-2010 are service firms, finance, rental, trading, hotel, and restaurant. Using LQ analysis, the base sectors in South Sumatera during 2001-2010 are mining and minerals, agriculture, and construction. On the whole, the variables of PMA, PMDN, goverment expenditure and labor force simultaneously influence the PDRB as high as $85 \%$. In partial view, PMDN, goverment expenditure and labor force have significant and positive influence toward PDRB, as indicated by a small probability value. Meanwhile, PMA has insignificant and negative influence toward PDRB.
\end{abstract}

Keywords: shift-share, location quotient, labor force, government expenditure

\section{PENDAHULUAN}

Pertumbuhan ekonomi merupakan salah satu indikator dalam menganalisis pembangunan ekonomi yang terjadi pada suatu negara ataupun daerah. Pertumbuhan ekonomi akan menghasilkan tambahan pendapatan masyarakat pada suatu periode tertentu, karena aktivitas perekonomian adalah suatu proses penggunaan faktor-faktor produksi untuk menghasilkan output. Proses ini akan menghasilkan aliran balas jasa terhadap faktor produksi yang dimiliki oleh masyarakat (Mankiw 2002).
Keberhasilan pembangunan yang dilakukan pemerintah pusat sebetulnya merupakan hasil dari keberhasilan pembangunan di daerah. Sejalan dengan semangat otonomi daerah, maka pemerintah daerah mendapat peran yang sangat besar dalam melakukan pembangunan. Oleh sebab itu pemerintah daerah harus mampu mendorong pelaku usaha untuk melakukan aktivitas investasi yang nantinya akan mendorong pertumbuhan ekonomian daerah tersebut.

Agar pembangunan di daerah menjadi berhasil maka diperlukan 
strategi yang tepat dan berkelanjutan. Salah satunya dengan menentukan daerah unggulan maupun sektor unggulan yang menjadi prioritas pembangunan. Sumatera Selatan sebagai salah satu provinsi di Indonesia sangat berkepentingan dalam melaksanakan pembangunan sesuai dengan semangat desentralisasi.

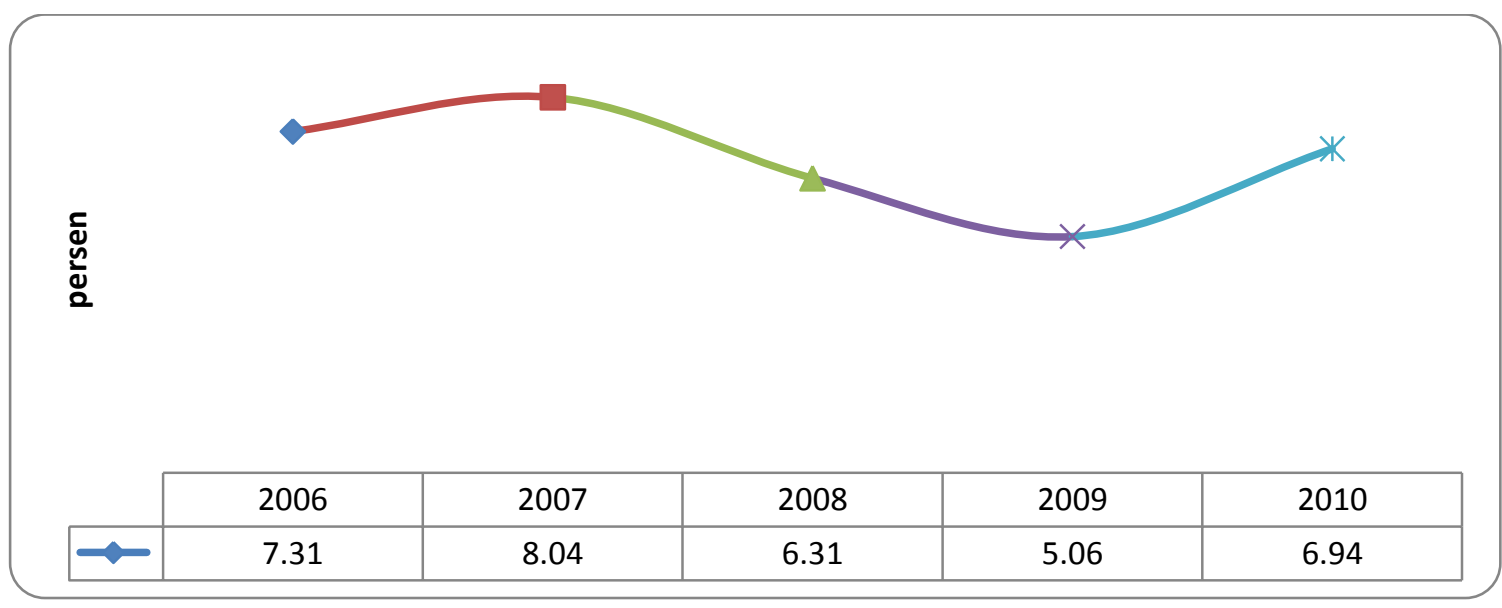

Sumber: BPS Sumatera Selatan

\section{Gambar 1. Pertumbuhan Ekonomi Sumatera Selatan 2006 - 2010}

Menurut Biro Pusat Statistik (BPS) Sumatera Selatan, pertumbuhan Produk Domestik Regional Bruto (PDRB) atas dasar harga konstan 2000, berfluktuasi tetapi cenderung meningkat (Gambar 1). Namun pendapatan domestik regional bruto perkapita relatif rendah. Sepanjang tahun 2006-2010 rata-rata pertumbuhan PDRB per kapita Sumatera Selatan sebesar 3.28\%, lebih rendah dibandingkan dengan Jambi dengan pertumbuhan rata-rata sebesar $4.14 \%$, Sumatera Utara sebesar $5.08 \%$ atau Lampung $4.2 \%$. Dengan demikian Provinsi Sumatera Selatan perlu meningkatkan laju pertumbuhan PDRB untuk mengejar provinsi lainnya di Sumatra. Agar pertumbuhan ekonomi lebih optimal, diperlukan kajian tentang faktor dominan dalam mendorong pertumbuhan ekonomi di Provinsi Sumatera Selatan. Salah satunya adalah dengan melakukan pengkajian terhadap pengaruh investasi asing (PMA), investasi dalam negeri (PMDN), dan angkatan kerja serta pengeluaran pemerintah terhadap pertumbuhan ekonomi Provinsi Sumatera Selatan.
Berdasarkan latar belakan di atas, penelitian bertujuan untuk: menganalisis besarnya perubahan Pendapatan Domestik Regional Bruto (PDRB) di Sumatera Selatan berdasarkan National Share (pertumbuhan nasional), Industry Mix (bauran industri) dan Regional Shift (keunggulan kompetitif) yang dimiliki menurut sektor-sektor ekonomi; Menentukan sektor unggulan Provinsi Sumatera Selatan; Menganalisis besarnya pengaruh PMA, PMDN, pengeluaran pemerintah dan angkatan kerja terhadap PDRB Sumatera Selatan.

\section{TINJAUAN LITERATUR \\ 1. Konsep Ekonomi Basis}

Perekonomian di suatu daerah bisa dibagi menjadi 2 sektor utama, yaitu sektor basis dan sektor non basis. Sektor basis adalah sektor yang mengekspor barang dan jasa ataupun tenaga kerja di luar batas perekonomian daerah yang bersangkutan (Priyarsono et al 2007). Sektor non basis adalah sektor yang menyediakan barang dan jasa yang dibutuhkan oleh masyarakat yang bertempat tinggal di dalam batas-batas 
daerah itu sendiri. Sektor ini tidak mengekspor barang, jasa maupun tenaga kerja sehingga luas lingkup produksi dan daerah pasar sektor non basis hanya bersifat lokal (Glasson dalam Priyarsono et al 2007).

\section{Teori investasi}

Sukirno (2007), mendefinisikan investasi sebagai pengeluaranpengeluaran untuk membeli barangbarang modal dan peralatan-peralatan produksi dengan tujuan untuk mengganti dan terutama menambah barang-barang modal dalam perekonomian yang akan digunakan untuk memproduksi barang dan jasa di masa datang. Hal ini berarti berkaitan dengan kemampuan perusahaan dalam rangka meningkatkan kapasitas produksi. Keinginan memproduksi lebih banyak terkait pula dengan estimasi keuntungan di masa datang.

Harrod-Domar menekankan pentingnya investasi dalam menciptakan pertumbuhan ekonomi yang berkelanjutan. Kedua ahli ekonomi tersebut, menyebut dua hal akibat adanya penambahan investasi. Pertama investasi menciptakan pendapatan, hal ini disebut dampak permintaan. Kedua, investasi menambah kapasitas produksi dengan adanya tambahan stok modal. Hal ini lazim disebut dampak penawaran.

Terdapat hubungan antara investasi dan pertumbuhan ekonomi. Walaupun sebesarnya tidak dapat dipastikan variabel mana yang mempengaruhi. Tetapi para ahli ekonomi sepakat bahwa tingkat investasi cenderung mempengaruhi pertumbuhan ekonomi. Donrbush (2008), mendefinisikan investasi sebagai arus pengeluaran yang menambah stok modal fisik. Dengan demikian teori investasi dapat dikatakan juga sebagai teori permintaan modal. Adapun dalam teori investasi dikenal istilah stok (stock) dan arus (flows).

\section{Pertumbuhan Penduduk dan} Angkatan kerja

Pertumbuhan penduduk diyakini mempengaruhi pertumbuhan ekonomi suatu daerah melalui penambahan angkatan kerja. Menurut Todaro (2000), pertumbuhan penduduk dan angkatan kerja dianggap sebagai salah satu faktor positif yang memacu pertumbuhan ekonomi, disamping modal. Pengaruh akumulasi modal dan angkatan kerja terhadap pertumbuhan ekonomi ditunjukkan dalam kurva kemungkinan produksi, yang merepresentasikan jumlah PDRB (output) maksimal jika seluruh sumber daya digunakan secara penuh. Seperti ditunjukkan pada Gambar 2 , dimana peningkatan kuantitas sumber daya (angkatan kerja) akan menggeser kurva keluar menjauhi titik origin secara sejajar, yaitu dari PP menuju P'P'. Dengan demikian maka kemampuan memproduksi sejumlah barang $\mathrm{X}$ dan $\mathrm{Y}$ akan bertambah banyak seiring dengan meningkatnya kuantitas angkatan kerja.

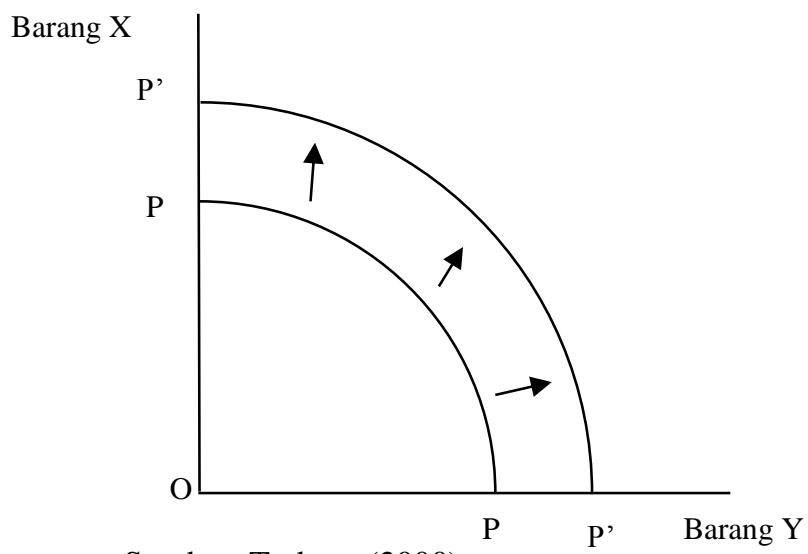

Sumber. Todaro, (2000)

Gambar 2. Kurva kemungkinan Produksi 


\section{METODE PENELITIAN}

\section{Jenis dan Sumber Data}

Penelitian ini menggunakan data sekunder kurun waktu 1993-2010, yang meliputi data Produk Domestik Regional Bruto (PDRB) Propinsi Sumatera Selatan; penanaman modal, baik Penanaman Modal Dalam Negeri (PMDN) maupun Penanaman Modal Asing (PMA); realisasi belanja pembangunan, belanja modal dan pemeliharaan Anggaran Pendapatan dan Belanja Daerah (APBD) Propinsi Sumatera Selatan; kependudukan Propinsi Sumatera Selatan. Data tersebut diperoleh dari BKPM Pusat; Bappeda Propinsi Sumatera Selatan; Badan Pusat Statistik Propinsi Sumatera Selatan; Badan Pusat Statistik Pusat; dan Instansi-instansi terkait lainnya.

\section{Analisis Shift Share (SS)}

Analisis Shift Share menggunakan rumus sebagai berikut:

$$
\begin{array}{r}
y_{i t}-y_{i o}=\Delta y=y_{i o}\left\{\left[Y_{t} / Y_{o}\right]-1\right\} \\
y_{i o}\left\{\left[Y_{i t} / Y_{i o}\right]-\left[Y_{t} / Y_{o}\right]\right\}+ \\
y_{i o}\left\{\left[y_{i t} / y_{i o}\right]-\left[Y_{i t} / Y_{i o}\right]\right\}
\end{array}
$$

dimana komponen:

$$
\begin{array}{r}
y_{i o}\left\{\left[Y_{t} / Y_{o}\right]-1\right\}=\text { unsur National Share } \\
\text { (pertumbuhan } \\
\text { nasional) }=[\mathbf{N S}] \\
y_{i o}\left\{\left[Y_{i t} / Y_{i o}\right]-\left[Y_{t} / Y_{o}\right]\right\}=\text { unsur Industry } \\
\text { Mix (bauran industri) } \\
=[\mathbf{I M}] \\
y_{i o}\left\{\left[y_{i t} / y_{i o}\right]-\left[Y_{i t} / Y_{i o}\right]\right\}=\text { unsur Regional } \\
\text { Shift (keunggulan } \\
\text { kompetitif) }=\text { [RS }]
\end{array}
$$

dimana NS merupakan komponen "Share", IM dan ketiga RS adalah komponen "Shift". Shift Share(SS) merupakan penjumlahan ketiga komponen diatas dan hasilnya harus sama dengan total perubahan dari data industri/sektor yang ada di daerah $(\Delta \mathrm{Y})$ (Bendavid 1991). keterangan:

$$
\begin{aligned}
\Delta y= & \text { Pertumbuhan total pendapatan } \\
& \text { daerah penelitian periode } \mathrm{t} \\
& \text { (rupiah) } \\
y_{i o}= & \text { Jumlah pendapatan sektor i } \\
& \text { daerah penelitian di tahun awal } \\
& \text { (rupiah) } \\
= & \text { Jumlah pendapatan sektor i } \\
& \text { daerah penelitian di tahun akhir } \\
& \text { (rupiah) } \\
= & \text { Jumlah pendapatan sektor i } \\
& \text { nasional di tahun awal (rupiah) } \\
Y_{i t} \quad & \text { Jumlah pendapatan sektor i } \\
& \text { nasional di tahun akhir (rupiah) } \\
Y_{i t} \quad & \text { Jumlah total pendapatan } \\
& \text { nasional di tahun awal (rupiah) } \\
Y_{o} \quad & \text { Jumlah total pendapatan } \\
& \text { nasional nasional di tahun akhir } \\
& \text { (rupiah) }
\end{aligned}
$$

Apabila Industry Mix + Regional Shift $\geq 0$ maka pertumbuhan sektor ke i di wilayah ke $\mathrm{j}$ termasuk ke dalam kelompok progresif (maju). Sementara itu, Industry Mix + Regional Shift $<0$ menunjukan bahwa pertumbuhan sektor ke $\mathrm{i}$ pada wilayah ke $\mathrm{j}$ tergolong pertumbuhannya lambat.

\section{Analisis Location Quetion (LQ)}

Metode LQ menganalisis sektor basis dan non basis dengan cara membandingkan pendapatan di sektor i pada daerah bawah terhadap pendapatan total semua sektor di daerah bawah dengan pendapatan di sektor i pada daerah atas terhadap pendapatan total semua sektor di daerah atas. Rumus yang digunakan adalah:

$$
L Q=\frac{S_{\mathrm{ib}} / \mathrm{S}_{\mathrm{b}}}{-\mathrm{S}_{\mathrm{ia}} / \mathrm{S}_{\mathrm{a}}}
$$

dimana :

$\mathrm{S}_{\mathrm{ib}}=$ pendapatan sektor $\mathrm{i}$ pada daerah bawah (rupiah)

$\mathrm{S}_{\mathrm{b}}=$ pendapatan total semua sektor daerah bawah (rupiah) 
$\mathrm{S}_{\mathrm{ia}}=$ pendapatan sektori pada daerah atas (rupiah)

$\mathrm{S}_{\mathrm{a}}=$ pendapatan total semua sektor pada daerah atas (rupiah)

Jika LQ > 1 maka sektor i dikategorikan sebagai sektor basis.

Jika LQ < 1 maka sektor i sebagai sektor non basis

\section{Model dan Analisis Faktor yang Memengaruhi Pertumbuhan Ekonomi}

Model yang digunakan untuk mengetahui faktor-faktor yang mempengaruhi pertumbuhan ekonomi adalah sebagai berikut:

$$
\begin{aligned}
\mathrm{PDRB}= & \beta_{0}+\beta_{1} P M A+\beta_{2} P M D N+\beta_{3} \\
& G E+\beta_{4} L F+\varepsilon
\end{aligned}
$$

dimana:

PDRB : Pertumbuhan Ekonomi yang di ukur dengan PDRB Riil

\begin{tabular}{|c|c|}
\hline$P M A$ & Penanaman \\
\hline
\end{tabular}
(rupiah)

PMDN : Penanaman Modal Dalam Negeri (rupiah)

GE : Pengeluaran Pemerintah Daerah (rupiah)

$L F \quad: \begin{aligned} & \text { Angkatan Kerja daerah } \\ & \text { (orang) }\end{aligned}$
$\beta_{0}:$ Konstanta

$\begin{array}{lll}\beta_{1,2,3} & : & \text { Koefisien } \\ & \text { (parameter yang diestimasi) }\end{array}$

\section{HASIL DAN PEMBAHASAN}

\section{Analisis Shift Share (SS)}

Analisis shift share menggunakan basis tahun 2001-2005 dan 2005-2010 (Tabel 1). Periode 2001-2005, seluruh sektor perekonomian di Sumatera Selatan mengalami perubahan positif. Perubahan terbesar adalah sektor pengangkutan dan komunikasi (sebesar $45 \%$ ), diikuti sektor bangunan; perdagangan, hotel dan restoran; serta sektor keuangan, persewaan dan jasa perusahaan. Di tingkat nasional, sektor pertambangan dan galian mengalami penurunan sebesar 2\%, sektor pengangkutan dan komunikasi mengalami pertumbuhan tertinggi (sebesar 55\%), diikuti oleh sektor keuangan, persewaan dan jasa perusahaan dan sektor bangunan, yang masing-masing mengalami perubahan sebesar 31\%, 29\% dan 28\%. Secara umum perkembangan PDRB Sumatera Selatan dan PDB nasional searah, kecuali sektor pertambangan dan galian.

\begin{tabular}{|c|c|c|c|c|c|c|c|c|}
\hline \multirow[t]{3}{*}{ Lapangan Usaha } & \multicolumn{2}{|c|}{ Sumatera Selatan } & \multicolumn{2}{|c|}{ Perubahan } & \multicolumn{2}{|c|}{ Nasional } & \multicolumn{2}{|c|}{ Perubahan } \\
\hline & \multirow{2}{*}{$\begin{array}{l}2001 \text { (juta) } \\
\text { PDRB awal }\end{array}$} & \multirow{2}{*}{$\begin{array}{c}2005 \text { (juta) } \\
\text { PDRB } \\
\text { akhir }\end{array}$} & \multirow[b]{2}{*}{$\begin{array}{c}\text { absolut } \\
\text { (juta) }\end{array}$} & \multirow[b]{2}{*}{$\%$} & \multirow{2}{*}{$\begin{array}{l}2001 \text { (juta) } \\
\text { PDB awal }\end{array}$} & \multirow{2}{*}{$\begin{array}{l}2005 \text { (juta) } \\
\text { PDB akhir }\end{array}$} & \multirow[b]{2}{*}{ absolut (juta) } & \multirow[b]{2}{*}{$\%$} \\
\hline & & & & & & & & \\
\hline Pertanian & $\begin{array}{l}7,950,978 \\
(18,91 \%)\end{array}$ & $\begin{array}{c}9,806,000 \\
(19,76 \%)\end{array}$ & $1,855,022$ & 23 & $\begin{array}{c}225,685,700 \\
(15,64 \%)\end{array}$ & $\begin{array}{r}253,881,700 \\
(14,50 \%)\end{array}$ & $28,196,000$ & 12 \\
\hline Pertambangan, dan & $12,962,160$ & $13,330,000$ & & & $168,244,300$ & $165,222,600$ & & \\
\hline Penggalian & $\begin{array}{l}(30,83 \%) \\
7,334,190\end{array}$ & $\begin{array}{l}(26,86 \%) \\
8,807,000\end{array}$ & 367,840 & 3 & $\begin{array}{c}(11,66 \%) \\
398,323,900\end{array}$ & $\begin{array}{r}(9,44 \%) \\
491,561,400\end{array}$ & $-3,021,700$ & -2 \\
\hline Industri Pengolahan & $\begin{array}{c}(17,44 \%) \\
189,393\end{array}$ & $\begin{array}{c}(17,74 \%) \\
231,000\end{array}$ & $1,472,810$ & 20 & $\begin{array}{l}(27,60 \%) \\
9,058,300\end{array}$ & $\begin{array}{r}(28,08 \%) \\
11,584,100\end{array}$ & $93,237,500$ & 23 \\
\hline Listrik, Gas, dan Air Bersih & $\begin{array}{c}(0,45 \%) \\
2,718,842\end{array}$ & $\begin{array}{c}(0,47 \%) \\
3,586,000\end{array}$ & 41,607 & 22 & $\begin{array}{c}(0,63 \%) \\
80,080,400\end{array}$ & $\begin{array}{r}(0,66 \%) \\
103,598,400\end{array}$ & $2,525,800$ & 28 \\
\hline Bangunan & $(6,47 \%)$ & $(7,22 \%)$ & 867,158 & 32 & $(5,55 \%)$ & $(5,92 \%)$ & $23,518,000$ & 29 \\
\hline Perdagangan, Hotel, dan & $5,053,572$ & $6,430,000$ & & & $234,273,000$ & $293,654,000$ & & \\
\hline Restoran & $(12,02 \%)$ & $(12,95 \%)$ & $1,376,428$ & 27 & $(16,24 \%)$ & $(16,77 \%)$ & $59,381,000$ & 25 \\
\hline Pengangkutan, dan & $1,385,284$ & $2,005,000$ & & & $70,276,100$ & $109,261,500$ & & \\
\hline Komunikasi & $(3,29 \%)$ & $(4,04 \%)$ & 619,716 & 45 & $(4,87 \%)$ & $(6,24 \%)$ & $38,985,400$ & 55 \\
\hline Keuangan, Persewaan, dan & $1,476,032$ & $1,860,000$ & & & $123,085,500$ & $161,252,200$ & & \\
\hline Jasa Perusahaan & $\begin{array}{c}(3,51 \%) \\
2,978,164\end{array}$ & $\begin{array}{c}(3,75 \%) \\
3,579,000\end{array}$ & 383,968 & 26 & $\begin{array}{c}(8,53 \%) \\
133,957,400\end{array}$ & $\begin{array}{r}(9,21 \%) \\
160,799,300\end{array}$ & $38,166,700$ & 31 \\
\hline Jasa-jasa & $(7,08 \%)$ & $(7,21 \%)$ & 600,836 & 20 & $(9,28 \%)$ & $(9,18 \%)$ & $26,841,900$ & 20 \\
\hline Total & $42,048,614$ & $49,634,000$ & $7,585,386$ & 18 & $1,442,984,600$ & $1,750,815,200$ & $307,830,600$ & 21 \\
\hline \multirow[t]{3}{*}{ Lapangan Usaha } & \multicolumn{2}{|c|}{ Sumatera Selatan } & \multicolumn{2}{|c|}{ Perubahan } & \multicolumn{2}{|c|}{ Nasional } & \multicolumn{2}{|c|}{ Perubahan } \\
\hline & 2005 (juta) & 2010 (juta) & & & 2005 (juta) & 2010 (juta) & & \\
\hline & PDRB awal & PDRB akhir & $\begin{array}{c}\text { absolut } \\
\text { (juta) }\end{array}$ & $\%$ & PDB awal & PDB akhir & absolut (juta) & $\%$ \\
\hline
\end{tabular}

Tabel 1. Perubahan PDRB Sumatera Selatan dan PDB Nasional 


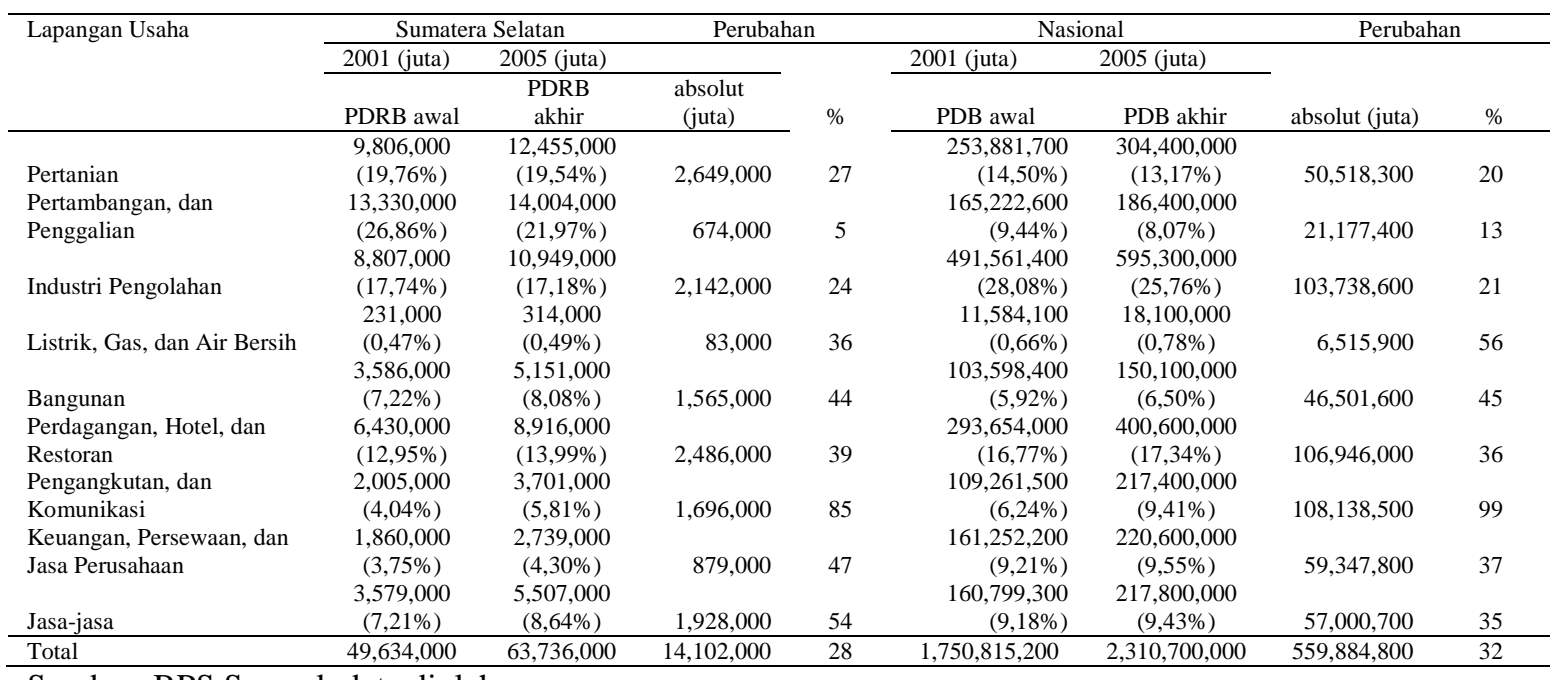

Sumber: BPS Sumsel, data diolah

Pada tahun 2005-2010 terdapat tiga sektor yang kontribusinya menurun terhadap PDRB Sumatera Selatan, yaitu sektor pertambangan dan galian, sektor pertanian dan sektor industri pengolahan. Walaupun terjadi penurunan kontribusi pada ketiga sektor di atas, namun sumbangan ketiga sektor tadi tetap terbesar dibanding sektor lain. Dengan demikian tidak terjadi perubahan struktur perekonomian di Provinsi Sumatera Selatan.

Tabel 2. Shift-Share (SS) Struktur Perekonomian Sumatera Selatan (Rp) 2001-2005

\begin{tabular}{|c|c|c|c|c|}
\hline Lapangan Usaha & NS & $\mathrm{IM}$ & $\mathrm{RS}$ & SS \\
\hline Pertanian & $1,696,174,947,624$ & $-702,821,023,613$ & $861,668,075,990$ & $1,855,022,000,000$ \\
\hline Pertambangan, dan Penggalian & $2,765,205,872,673$ & $-2,998,008,760,331$ & $600,642,887,658$ & $367,840,000,000$ \\
\hline Industri Pengolahan & $1,564,596,121,271$ & $152,151,330,049$ & $-243,937,451,320$ & $1,472,810,000,000$ \\
\hline Listrik, Gas, dan Air Bersih & $40,403,037,445$ & $12,406,964,366$ & $-11,203,001,810$ & $41,607,000,000$ \\
\hline Bangunan & $580,008,105,537$ & $218,461,009,952$ & $68,688,884,511$ & $867,158,000,000$ \\
\hline Perdagangan, Hotel, dan Restoran & $1,078,073,945,421$ & $202,851,124,613$ & $95,502,929,966$ & $1,376,428,000,000$ \\
\hline Pengangkutan, dan Komunikasi & $295,521,285,042$ & $472,959,506,013$ & $-148,764,331,056$ & $619,716,460,000$ \\
\hline \multicolumn{5}{|l|}{ Keuangan, Persewaan, dan Jasa } \\
\hline Perusahaan & $314,880,507,962$ & $142,811,576,681$ & $-73,723,784,644$ & $383,968,300,000$ \\
\hline Jasa-jasa & $635,329,033,323$ & $-38,575,287,195$ & $4,082,253,872$ & $600,836,000,000$ \\
\hline Total & $8,970,192,856,298$ & $-2,537,763,559,465$ & $1,152,956,463,167$ & $7,585,385,760,000$ \\
\hline \multicolumn{5}{|l|}{$2005-2010$} \\
\hline Lapangan Usaha & NS & IM & $\mathrm{RS}$ & SS \\
\hline Pertanian & $3,135,813,733,397$ & $-1,184,580,344,775$ & $697,766,611,378$ & $2,649,000,000,000$ \\
\hline Pertambangan, dan Penggalian & $4,262,736,800,549$ & $-2,554,164,595,536$ & $-1,034,572,205,013$ & $674,000,000,000$ \\
\hline Industri Pengolahan & $2,816,348,312,260$ & $-957,728,310,364$ & $283,379,998,104$ & $2,142,000,000,000$ \\
\hline Listrik, Gas, dan Air Bersih & $73,870,382,665$ & $56,064,001,534$ & $-46,934,384,199$ & $83,000,000,000$ \\
\hline Bangunan & $1,146,749,749,945$ & $462,876,823,438$ & $-44,626,573,383$ & $1,565,000,000,000$ \\
\hline Perdagangan, Hotel, dan Restoran & $2,056,218,876,784$ & $285,526,102,001$ & $144,255,021,215$ & $2,486,000,000,000$ \\
\hline Pengangkutan, dan Komunikasi & $641,169,338,717$ & $1,343,223,082,218$ & $-288,392,420,935$ & $1,696,000,000,000$ \\
\hline \multicolumn{5}{|l|}{ Keuangan, Persewaan, dan Jasa } \\
\hline Perusahaan & $594,800,483,797$ & $89,760,148,554$ & $194,439,367,649$ & $879,000,000,000$ \\
\hline Jasa-jasa & $1,144,511,253,501$ & $124,185,222,790$ & $659,303,523,709$ & $1,928,000,000,000$ \\
\hline Total & $15,872,218,931,615$ & $-2,334,837,870,141$ & $564,618,938,526$ & $14,102,000,000,000$ \\
\hline
\end{tabular}

Di tingkat nasional, pada tahun 2005-2010 ada tiga sektor yang turun kontribusinya terhadap PDB yaitu sektor pertanian; pertambangan dan galian; serta sektor industri pengolahan. Sumbangan ketiga sektor tersebut tetap yang terbesar dibanding sektor lainnya, yang mengindikasi perekonomian nasional tidak terjadi perubahan struktur perekonomianAnalisis Shift Share menjelaskan tentang bagaimana PDRB Sumatera Selatan dapat dilihat berdasarkan komponen National Share 
(NS), Industri Mix (IM) dan Regional Shift (RS). Laju pertumbuhan PDB nasional sebesar $21 \%$ telah menambah PDRB Sumatera Selatan total sebesar 7585 milyar lebih (penjumlahan unsur National hare (NS), Industri Mix (IM) dan Regional Shift (RS)). Pada unsur National Share, sektor yang paling besar menambah PDRB adalah sektor pertambangan dan galian; pertanian; industri pengolahan; serta perdagangan hotel dan restoran. Sumber pertumbuhan tiap-tiap sektor di wilayah Sumatera Selatan tahun 2001-2005 dan tahun 2005-2010, seperti pada Tabel 2.

\section{Pergeseran Bersih}

\section{Pergeseran Bersih Sumatera Selatan Tahun 2001-2005}

Pergeseran bersih adalah jumlah komponen Industri Mix (IM) dan keunggulan kompetitip (RS) atau persentasinya nilai (IM) dan nilai (RS). Pergeseran bersih yang nilainya positif artinya pertumbuhan PDRB Sumatera Selatan tergolong kelompok progresif atau maju, sebaliknya jika nilainya negatif berarti pertumbuhan PDRB termasuk kelompok lambat.

Tabel 3 menunjukkan bahwa sektor yang maju adalah sektor perdagangan, hotel dan restoran, dikuti sektor bangunan, sektor keuangan, sewa dan jasa perusahaan, sektor pengangkutan dan komunikasi, sektor listrik, gas dan air bersih, dan sektor pertanian. Sedangkan sektor yang tergolong lamban adalah sektor pertambangan dan galian, sektor industri pengolahan dan sektor jasa-jasa.

Tabel 3. Pergeseran Bersih PDRB Sumatera Selatan 2001-2005

\begin{tabular}{lccccc}
\hline \multicolumn{1}{c}{ Lapangan Usaha } & IM & RS & PB & \%IM & $\%$ RS \\
\hline Pertanian & $-702,821,023,613$ & $861,668,075,990$ & $158,847,052,376$ & -8.84 & 10.84 \\
Pertambangan, dan & $-2,998,008,760,331$ & $600,642,887,658$ & $-2,397,365,872,673$ & -23.13 & 4.63 \\
Penggalian & $152,151,330,049$ & $-243,937,451,320$ & $-91,786,121,271$ & 2.07 & -3.33 \\
Industri Pengolahan & $12,406,964,366$ & $-11,203,001,810$ & $1,203,962,555$ & 6.55 & -5.92 \\
Listrik, Gas, dan Air Bersih & $218,461,009,952$ & $68,688,884,511$ & $287,149,894,463$ & 8.04 & 2.53 \\
Bangunan & & & & \\
Perdagangan, Hotel, dan & $202,851,124,613$ & $95,502,929,966$ & $298,354,054,579$ & 4.01 & 1.89 \\
Restoran & & & & \\
Pengangkutan, dan & $472,959,506,013$ & $-148,764,331,056$ & $324,195,174,958$ & 34.14 & -10.74 \\
Komunikasi & & & & \\
Keuangan, Persewaan, dan & $142,811,576,681$ & $-73,723,784,644$ & $69,087,792,038$ & 9.68 & -4.99 \\
Jasa Perusahaan & $-38,575,287,195$ & $4,082,253,872$ & $-34,493,033,323$ & -1.30 & 0.14 \\
Jasa-jasa & & & & & \\
\hline
\end{tabular}

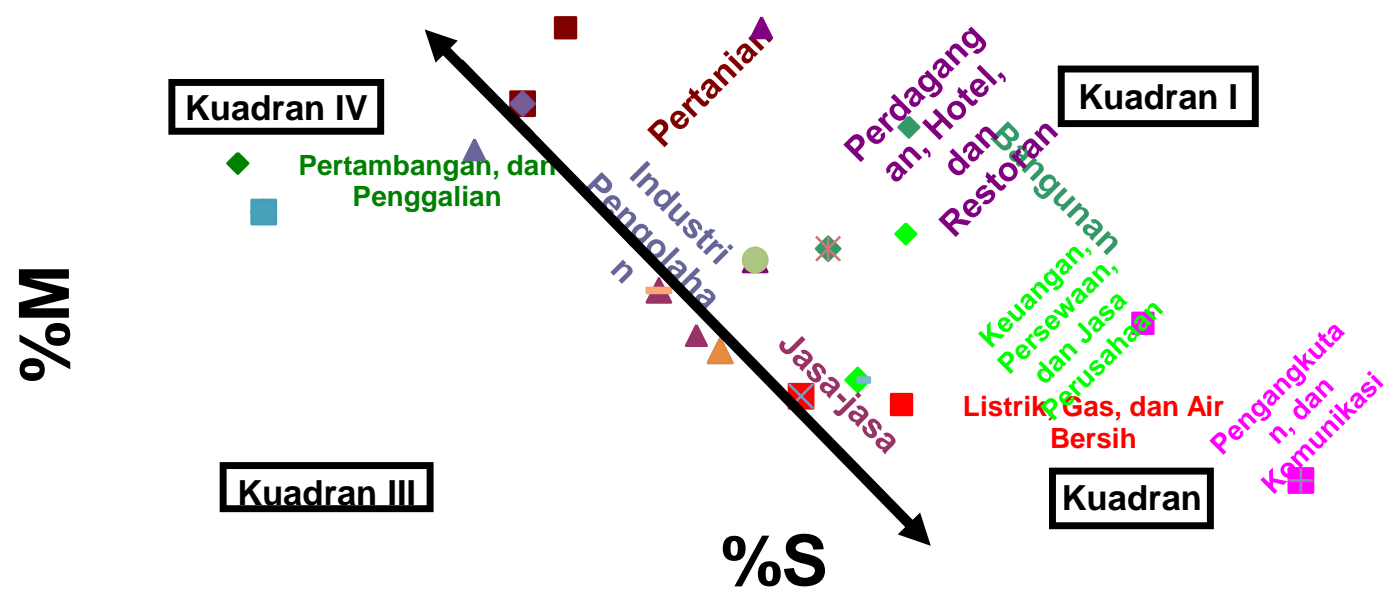

Gambar 3. Profil Pertumbuhan Perekonomian Sumatera Selatan 2001-2005 
Profil pertumbuhan sektor-sektor perekonomian berdasarkan PDRB dibagi dalam empat kuadran. Kuadran I menggambarkan sektor yang memiliki pertumbuhan cepat dengan keunggulan kempetitif yang baik. Kuadran II menggambarkan pertumbuhan cepat tetapi lemah dalam keunggulan kompetitif. Sektor III menggambarkan pertumbuhan yang lambat dan lemah dalam keunggulan kompetitif. Sedangkan kuadran IV menggambarkan pertumbuhan cepat dan lemah dalam keunggulan kompetitif. Gambar 3 menunjukkan posisi setiap sektor dilihat dari kecepatan pertumbuhan dan kekuatan persaingan kompetitif.

Sektor bangunan dan perdagangan, hotel dan Restoran berada pada kuadran I. dengan demikian kedua sektor tersebut merupakan sektor yang pertumbuhannya cepat dan sektor yang unggul secara kompetitif. Sektor industri pengolahan; listrik, gas dan air bersih; pengangkutan dan komunikasi serta; sektor keuangan sewa dan jasa keuangan berada pada kuadran II yang berarti keempat sektor tersebut memiliki pertumbuhan cepat namun kurang mempunyai keunggulan kompetitif.
Sedangkan sektor jasa-jasa; pertanian; serta sektor pertambangan dan galian berada pada kuadran IV, yaitu sektor yang pertumbuhannya cepat tetapi kurang mempunyai daya saing kompetitif.

Bila dilihat dengan pergeseran bersih, maka yang termasuk sektor yang maju adalah sektor perdagangan, hotel dan restoran, bangunan, listrik, gas dan air bersih, pengangkutan dan komunikasi, dan sektor pertanian. Sedangkan sektor jasa-jasa, industri pengolahan dan sektor tambang dan galian termasuk sektor lambat, sebab posisi ketiga sektor tersebut berada di sebelah kiri garis yang memisahkan dan memotong dengan sudut $45^{\circ}$ dapat dilihat pada Gambar 3 .

\section{Pergeseran Bersih Sumatera Selatan Tahun 2005-2010}

Pada periode 2005-2010, sektor yang maju adalah sektor perdagangan, hotel dan restoran; keuangan, sewa dan jasa perusahaan jasa-jasa; bangunan; pengangkutan dan komunikasi, serta sektor listrik gas dan air bersih (Gambar 4).

Tabel 4. Pergeseran Bersih PDRB Sumatera Selatan 2005-2010

\begin{tabular}{lccccc}
\hline \multicolumn{1}{c}{ Lapangan Usaha } & IM & RS & PB & \% IM & \% RS \\
\hline Pertanian & $-1,184,580,344,775$ & $697,766,611,378$ & $-486,813,733,397$ & -12.08 & 7.12 \\
Pertambangan, dan & & & & & \\
Penggalian & $-2,554,164,595,536$ & $-1,034,572,205,013$ & $-3,588,736,800,549$ & -19.16 & -7.76 \\
Industri Pengolahan & $-957,728,310,364$ & $283,379,998,104$ & $-674,348,312,260$ & -10.87 & 3.22 \\
Listrik, Gas, dan Air Bersih & $56,064,001,534$ & $-46,934,384,199$ & $9,129,617,335$ & 24.27 & -20.32 \\
Bangunan & $462,876,823,438$ & $-44,626,573,383$ & $418,250,250,055$ & 12.91 & -1.24 \\
Perdagangan, Hotel, dan & & & & & \\
Restoran & $285,526,102,001$ & $144,255,021,215$ & $429,781,123,216$ & 4.44 & 2.24 \\
Pengangkutan, dan & & & & & \\
Komunikasi & $1,343,223,082,218$ & $-288,392,420,935$ & $1,054,830,661,283$ & 66.99 & -14.38 \\
Keuangan, Persewaan, dan & & & & & \\
Jasa Perusahaan & $89,760,148,554$ & $194,439,367,649$ & $284,199,516,203$ & 4.83 & 10.45 \\
Jasa-jasa & $124,185,222,790$ & $659,303,523,709$ & $783,488,746,499$ & 3.47 & 18.42 \\
\hline
\end{tabular}

Apabila dibandingkan antara periode 2001-2005 dengan periode 20052010, maka terdapat perbedaan pada sektor pertanian yang pada periode 20012005 merupakan sektor yang cepat menjadi sektor lambat pada periode 2005-2010. Sektor jasa yang pada periode 2001-2005 merupakan sektor yang lambat menjadi sektor cepat pada periode 2005-2010. Sedangkan sektor lainnya relatif tidak berubah. Dengan demikian terjadi perubahan sektor progresif di Provinsi Sumatera Selatan dari sektor pertanian menjadi sektor jasa. 


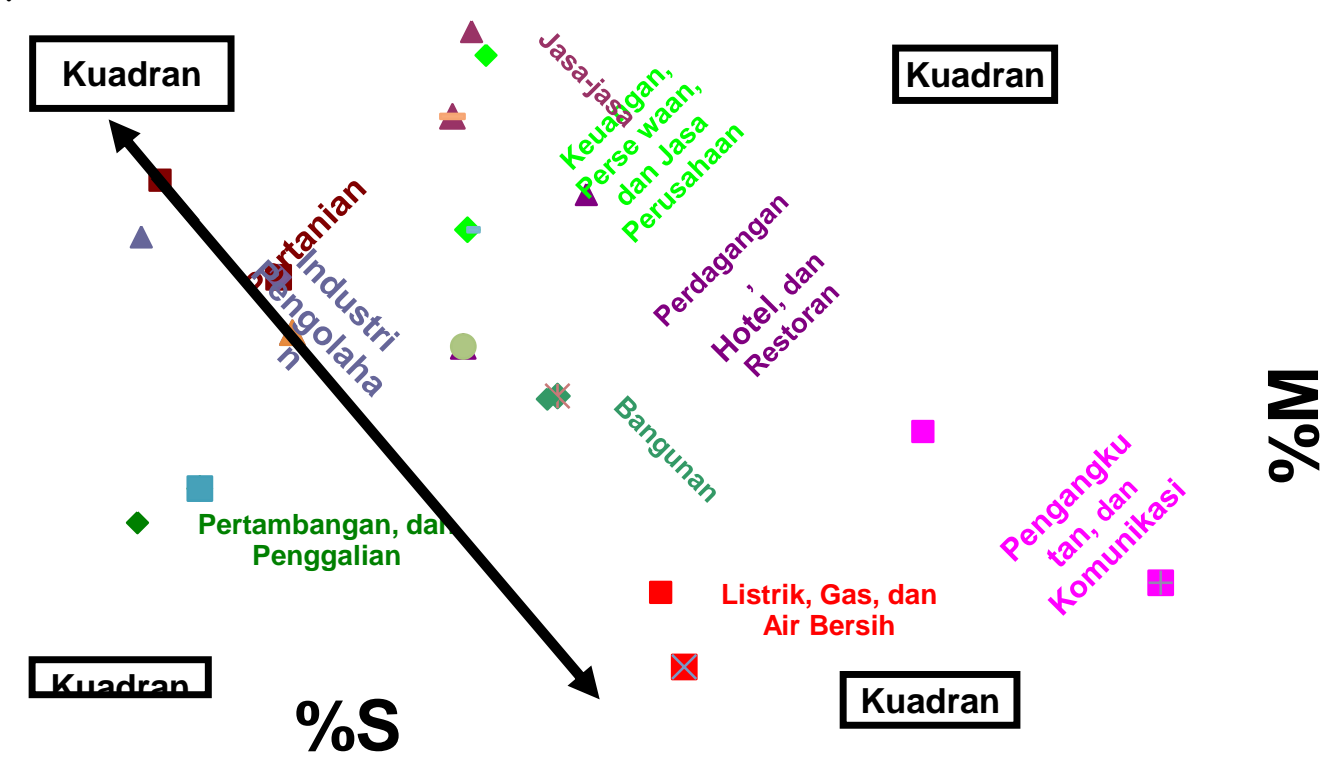

Gambar 4. Profil Pertumbuhan Sektor-Sektor Perekonomian atas Dasar PDRB Sumatera Selatan Tahun 2005-2010

\section{Analisis Location Quotient (LQ)}

Metode LQ digunakan untuk mengetahui sektor andalan di suatu daerah dengan menggunakan data pendapatan. Dalam penelitian data PDRB Sumatera Selatan sebagai daerah bawah dan PDB Nasional sebagai daerah atas. Dari analisis LQ selama 10 tahun didapatkan hasil bahwa sektor yang menjadi andalan Sumatera Selatan adalah sektor pertambangan dan galian; pertanian; serta sektor bangunan. Diharapkan dengan memprioritaskan ketiga sektor ini nantinya akan mendorong sumbangan sektor lain terhadap pertumbuhan ekonomi Sumatera Selatan. Adapun perhitungan dari analisis LQ dapat dilihat pada Tabel 5.

Tabel 5. Location Quotient Perekonomian Sumatera Selatan 2001-2010

\begin{tabular}{|c|c|c|c|c|c|c|c|c|c|c|}
\hline Lapangan Usaha & 2001 & 2002 & 2003 & 2004 & 2005 & 2006 & 2007 & 2008 & 2009 & 2010 \\
\hline Pertanian & 1.21 & 1.23 & 1.24 & 1.26 & 1.36 & 1.41 & 1.45 & 1.46 & 1.45 & 1.48 \\
\hline $\begin{array}{c}\text { Pertambangan, } \\
\text { dan Penggalian }\end{array}$ & 2.64 & 2.68 & 2.81 & 2.99 & 2.85 & 2.82 & 2.78 & 2.83 & 2.77 & 2.72 \\
\hline $\begin{array}{c}\text { Industri } \\
\text { Pengolahan }\end{array}$ & 0.63 & 0.62 & 0.62 & 0.63 & 0.63 & 0.64 & 0.65 & 0.65 & 0.65 & 0.67 \\
\hline $\begin{array}{c}\text { Listrik, Gas, dan } \\
\text { Air Bersih }\end{array}$ & 0.72 & 0.69 & 0.68 & 0.69 & 0.70 & 0.72 & 0.70 & 0.67 & 0.62 & 0.63 \\
\hline Bangunan & 1.17 & 1.18 & 1.18 & 1.18 & 1.22 & 1.21 & 1.21 & 1.21 & 1.22 & 1.24 \\
\hline $\begin{array}{c}\text { Perdagangan, } \\
\text { Hotel, dan } \\
\text { Restoran }\end{array}$ & 0.74 & 0.76 & 0.76 & 0.77 & 0.77 & 0.79 & 0.79 & 0.80 & 0.82 & 0.81 \\
\hline $\begin{array}{c}\text { Pengangkutan, } \\
\text { dan Komunikasi }\end{array}$ & 0.68 & 0.67 & 0.64 & 0.63 & 0.65 & 0.63 & 0.63 & 0.62 & 0.62 & 0.62 \\
\hline $\begin{array}{c}\text { Keuangan, } \\
\text { Persewaan, dan } \\
\text { Jasa Perusahaan }\end{array}$ & 0.41 & 0.41 & 0.40 & 0.40 & 0.41 & 0.42 & 0.42 & 0.43 & 0.44 & 0.45 \\
\hline Jasa-jasa & 0.76 & 0.77 & 0.78 & 0.77 & 0.79 & 0.80 & 0.82 & 0.87 & 0.90 & 0.92 \\
\hline
\end{tabular}

Sumber: BPS Sumatera Selatan 
Dari analisis LQ sektor basis adalah sektor pertambangan dan galian; sektor pertanian; serta sektor bangunan. Sedangkan dari analisis shift share, menunjukkan terjadinya pergeseran sektor progresif dari sektor pertanian menuju sektor jasa-jasa. Sektor basis di Provinsi Sumatera Selatan merupakan sektor yang sudah jenuh dan sulit untuk ditingkatkan lagi kontribusinya. Sehingga penting bagi pengambil kebijakan untuk juga mulai memperhatikan sektor-sektor lain yang termasuk sektor yang progresif. Menurut Priyarsono et al. (2007) sektor yang merupakan sektor basis dan non basis di suatu daerah tidaklah bersifat statis melainkan dinamis. Sektor basis atau non basis bisa mengalami kemajuan ataupun kemunduran sehingga definisi dari sektor basis dan non basis dapat saja bergeser setiap tahunnya. Hal lain yang perlu dipertimbangkan bahwa sektor pertanian termasuk sektor yang sangat dipengaruhi oleh variabel iklim dan cuaca yang merupakan variabel yang tidak dapat dikontrol oleh pengambil kebijakan. Selain itu pula sektor pertambangan dan galian termasuk sumber daya alam yang tidak dapat diperbaharui, sehingga pemerintah provinsi Sumatera Selatan perlu juga memperhatikan sektor-sektor yang progresif seperti yang ditunjukkan dalam analisis shift share. Glasson (1977) dalam Priyarsono et al. (2007) menulis bahwa semakin banyak sektor basis dalam suatu daerah akan menambah arus pendapatan ke daerah tersebut, menambah permintaan terhadap barang dan jasa di dalamnya dan menimbulkan kenaikan volume sektor non basis. Dengan demikian sektor basis menjadi penggerak utama dalam perekonomian daerah, dengan harapan arus pendapatan juga akan bertambah pada sektor non basis. Pada akhirnya akan berdampak positif pada perekonomian daerah secara keseluruhan. Adapun sektor yang progresif di Sumatera Selatan diantaranya adalah sektor jasa-jasa; keuangan, persewaan dan jasa perusahaan, perdagangan, hotel dan restoran, listrik, gas dan air bersih; dan sektor pengangkutan dan komunikasi.

\section{Analisis Faktor-Faktor yang Mempengaruhi PDRB Sumatera Selatan}

Analisis menggunakan model regresi, faktor-faktor yang mempengaruhi pertumbuhan ekonomi di Sumatera Selatan, diperoleh hasil seperti ditunjukkan pada Tabel 6 . Nilai Rsquared sebesar 0.86 menunjukkan bahwa PDRB Sumatera Selatan dipengaruhi oleh variabel PMA, PMDN, pengeluaran pemerintah dan angkatan kerja sebesar 86\% sisanya dipengaruhi oleh faktor lain di luar model. Persamaan regresi linier pertumbuhan ekonomi di Sumatera Selatan, adalah sebagai berikut:

$$
\begin{aligned}
\mathrm{PDRB}= & 13.77-0.007 * \mathrm{PMA}+ \\
& 0.04 * \mathrm{PMDN}+0.09 * \mathrm{GE}+ \\
& 0.97 * \mathrm{LF}
\end{aligned}
$$

Dari 4 variabel penduga yang dimasukkan dalam model, ada satu variabel yang secara statistik tidak berpengaruh nyata dan memiliki tanda negatif, yaitu variabel penanaman modal asing (PMA). Variabel lainnya memiliki pengaruh positif sebesar nilai koefisiennya. Koefisien variable PMDN sebesar 0.04 (pembulatan dari 0.0378), menunjukkan bahwa apabila PMDN bertambah 1 Milyar, maka PDRB bertambah sebanyak 0.04 Milyar (variabel lain dianggap tetap). Variabel pengeluaran pemerintah memiliki nilai 0.09 , berarti pertambahan pengeluaran pemerintah sebesar 1 milyar, maka PDRB bertambah sebesar 0.09 milyar, dan variabel angkatan kerja bila bertambah $1 \%$ maka PDRB bertambah sebanyak $97 \%$. 
Tabel 6. Koefisien Variabel Penduga PDRB Sumatera Selatan

$\begin{array}{crrrr}\text { Variable } & \text { Coefficient } & \text { Std. Error } & \text { t-Statistic } & \text { Prob. } \\ \text { C } & 13.76667 & 5.916738 & 2.326732 & 0.0383 \\ \text { LPMA } & -0.007178 & 0.013646 & -0.526029 & 0.6085 \\ \text { LPMDN } & 0.037778 & 0.011715 & 3.224823 & 0.0073 \\ \text { LGE } & 0.088441 & 0.025202 & 3.509246 & 0.0043 \\ \text { LLF } & 0.969794 & 0.412630 & 2.350273 & 0.0367\end{array}$

\begin{tabular}{|c|c|c|c|}
\hline R-squared & 0.856881 & $\begin{array}{l}\text { F-statistic } \\
\text { Prob(F-statistic) }\end{array}$ & $\begin{array}{l}17.96152 \\
0.000053\end{array}$ \\
\hline
\end{tabular}

Berdasarkan nilai koefisien penduga, diperoleh nilai elastisitas PMDN yaitu sebesar 0.001, elastisitas pengeluaran pemerintah 0.002 dan elastisitas paling besar adalah angkatan kerja 0.007. Artinya bahwa PDRB lebih responsif dipengaruhi oleh variabel angkatan kerja. Perubahan 1\% angkatan kerja akan berpengaruh terhadap PDRB sebesar $0.7 \%$.

Variabel PMA tidak signifikan pengaruhnya terhadap PDRB. Hal ini sejalan dengan hasil penelitian Prasmuko et al. (2000) bahwa kendala investasi adalah cost of capital tinggi dan aksesibilitas yang rendah. Kemudian lemahnya permintaan eksternal dan kondisi ketidakpastian memperparah investasi. Menurut peneliti, bahwa daerah yang terkena dampak buruk pada investasi di daerah Sumatera dan Jabalnustra penyebabnya adalah rendahnya daya serap eksternal dan ketidakpastian global dan tingginya risiko yang dihadapi investor.

Variabel PMDN secara signifikan berpengaruh positif terhadap PDRB Sumatera Selatan. Penelitian (Makmun dan Yasin 2003) menyebutkan bahwa pengaruh PMDN signifikan, sedangkan pengaruh PMA tidak signifikan terhadap PDB sektor pertanian. Disebutkan bahwa nilai investasi yang disetujui menunjukkan penurunan akibat dari krisis ekonomi global. Penelitian Sodik (2007) menunjukkan bahwa investasi swasta tidak signifikan pengaruhnya terhadap pertumbuhan ekonomi regional. Faktor penyebabnya adalah masih banyak peraturan yang tumpang tindih baik tingkat vertikal maupun horizontal, dan buruknya prosedur dan tidak kondusifnya iklim bisnis di daerah. Tabel 7 menunjukkan nilai PMA dan PMDN di Sumatera Selatan.

Tabel 7. Perkembangan Persetujuan Investasi di Sumatera Selatan (rupiah)

\begin{tabular}{|c|r|r|}
\hline Tahun & \multicolumn{1}{|c|}{ PMA } & \multicolumn{1}{|c|}{ PMDN } \\
\hline 2005 & $53,638,702,390,000,00$ & $1,370,900,000,00$ \\
\hline 2006 & $31,429,522,520,000,00$ & $2,983,200,000,00$ \\
\hline 2007 & $82,915,432,510,600,00$ & $4,857,100,000,00$ \\
\hline 2008 & $10,716,599,473,200,00$ & $378,500,000,00$ \\
\hline 2009 & $6,025,912,000,000,00$ & $580,300,000,00$ \\
\hline 2010 & $14,823,220,320,000,00$ & $1,738,400,000,00$ \\
\hline
\end{tabular}

Sumber : BPS, data diolah. 
Secara teori meningkatnya pengeluaran pemerintah akan meningkatkan permintaan agregat, yang pada akhirnya nanti akan meningkatkan pendapatan atau output. Hal ini sesuai dengan penelitian Raharjo (2006) yang meneliti tentang pengaruh pengeluaran pemerintah, investasi dan angkatan kerja terhadap pertumbuhan ekonomi Semarang. Selanjutnya penelitian Rustiono (2009) menunjukkan bahwa investasi, tenaga kerja dan belanja pemerintah daerah memiliki pengaruh positif terhadap pertumbuhan ekonomi Provinsi Jawa Tengah.

\section{KESIMPULAN DAN SARAN}

Hasil analisis Shift-Share periode 2001-2005, menunjukkan sektor yang progresif/maju di Sumatera Selatan seluruh sektor, kecuali sektor pertambangan dan galian, sektor industri pengolahan dan sektor jasa-jasa. ShiftShare periode 2005-2010, hasilnya hampir sama dimana sektor yang progresif/maju di Sumatera Selatan hampir semua sektor kecuali sektor pertambangan dan galian; sektor industri pengolahan; serta sektor pertanian. Dengan demikian terjadi perubahan sektor progresif dari sektor pertanian menuju sektor jasa-jasa di Sumatera Selatan. Analisis LQ menujukkan sektor basis adalah sektor pertambangan dan penggalian; sektor pertanian; serta sektor bangunan.

Secara empiris, variabel PMA, PMDN, pengeluaran pemerintah dan angkatan kerja mempunyai pengaruh terhadap variabel PDRB Sumsel selama kurun waktu 1993-2010. Variabel PMDN, pengeluaran pemerintah dan angkatan kerja berpengaruh positif terhadap PDRB, sedangkan variabel PMA berpengaruh negatif dan tidak signifikan terhadap PDRB.

\section{Saran}

Walaupun sektor basis Provinsi Sumatera Selatan adalah sektor pertambangan dan penggalian; sektor pertanian dan sektor bangunan, namun dalam proses pembangunan Pemerintah daerah Provinsi tetap harus memberi perhatian lebih terhadap sektor progresif/maju, mengingat sektor basis sudah jenuh terlihat dari kontribusinya yang semakin menurun.

Pemerintah Provinsi Sumatera Selatan hendaknya lebih meningkatkan performa variabel yang mendorong pertumbuhan PDRB dengan prioritas kebijakan yang mendukung produktivitas angkatan kerja, disusul dengan menambah masuknya investasi dalam bentuk PMDN dan selanjutnya memperbesar pengeluaran pemerintah pada sektor-sektor progresif yaitu sektor jasa-jasa, sektor keuangan, persewaan dan jasa perusahaan serta sektor perdagangan, hotel dan restoran.

\section{DAFTAR PUSTAKA}

Bendavid, AL. 1991. Regional and Local Economic Analysis for Practioners, 4 th Ed. New York: Praeger.

BPS Pusat. 2009. Sumatera Selatan Dalam Angka. Jakarta.

BPS Sumsel. 2010. PDRB Sumatera Selatan Menurut Lapangan Usaha.

Dornbursch, R. 2008. Makroekonomi, Edisi Sepuluh, Jakarta: Media Global Edukasi

Gujarati, Damodar N. 2002. Ekonometrika Dasar. Edisi Terjemahan. Jakarta: Erlangga.

Makmun dan Yasin. 2003. Pengaruh Investasi dan Tenaga Kerja terhadap PDB Sektor Pertanian. Kajian Ekonomi dan Keuangan, Volume 7, No.3. September 2003.

Mankiw, GN, 2007. Makroekonomi, edisi keenam. Jakarta: Erlangga. 
Priyarsono, DS., Sahara, dan Firdaus. 2007. Ekonomi Regional, Jakarta: Universitas Terbuka.

Raharjo. 2006. Pengaruh Pengeluaran Pemerintah, Investasi Swasta dan Angkatan Kerja terhadap Pertumbuhan Ekonomi Tahun 1982 - 2003. Tesis. Sekolah Pasca Sarjana Undip. Semarang.

Rustiono. 2009. Pengaruh Investasi, Tenaga Kerja dan Pengeluaran Pemerintah Pertumbuhan Ekonomi Jawa
Tengah. Tesis. Sekolah Pasca Sarjana. Semarang. Universitas Diponegoro.

Sodik. 2007. Pengeluaran Pemerintah dan Pertumbuhan Ekonomi Regional. Jurnal Ekonomi Pembangunan, Vol 12, No.1. April 2007.

Sukirno, S. 2007. Makroekonomi Modern. Jakarta: Rajagrafindo Persada.

Todaro, P. 2000. Pembangunan Ekonomi. Jakarta: Erlangga. 